\title{
Effects of the Replacement of Co with Ni on the Microstructure, Mechanical Properties, and Age Hardening of $\mathrm{AlCo}_{1-x} \mathrm{CrFeNi}_{1+x}$ High-Entropy Alloys
}

\author{
Che-Fu Lee and Tao-Tsung Shun *(1)
}

check for updates

Citation: Lee, C.-F.; Shun, T.-T.

Effects of the Replacement of Co with $\mathrm{Ni}$ on the Microstructure, Mechanical Properties, and Age Hardening of $\mathrm{AlCo}_{1-x} \mathrm{CrFeNi}_{1+x}$ High-Entropy Alloys. Materials 2021, 14, 2665. https://doi.org/10.3390/ma14102665

Academic Editor: Jeong Min Park

Received: 26 April 2021

Accepted: 10 May 2021

Published: 19 May 2021

Publisher's Note: MDPI stays neutral with regard to jurisdictional claims in published maps and institutional affiliations.

Copyright: (c) 2021 by the authors. Licensee MDPI, Basel, Switzerland. This article is an open access article distributed under the terms and conditions of the Creative Commons Attribution (CC BY) license (https:// creativecommons.org/licenses/by/ $4.0 /)$.
Department of Materials Science and Engineering, Feng Chia University, Taichung 407, Taiwan; p0100064@o365.fcu.edu.tw

* Correspondence: ttshun@fcu.edu.tw

\begin{abstract}
In this study, effects of the replacement of Co with Ni on the microstructure, mechanical properties, and age hardening of high-entropy alloys of $\mathrm{AlCo}_{1-\mathrm{x}} \mathrm{CrFeNi}_{1+\mathrm{x}}(\mathrm{x}=$ molar ratio; $\mathrm{x}=0$, $0.5,1$, denoted as $\mathrm{X}_{0}, \mathrm{X}_{0.5}$, and $\mathrm{X}_{1}$, respectively) were investigated. These three alloys exhibited a dendritic structure comprising an ordered BCC matrix, a BCC phase, and an FCC or an ordered FCC phase. From $X_{0}$ to $X_{1}$ alloys, the yield stress and compressive stress decreased from 1202 and $1790 \mathrm{MPa}$ to 693 and $1537 \mathrm{MPa}$, respectively. However, fracture strain increased from 0.15 to 0.42 . Peak age hardening at $600{ }^{\circ} \mathrm{C}$ for the $\mathrm{X}_{0}$ alloy was due to the precipitation of the $(\mathrm{Cr}, \mathrm{Fe})$-rich $\sigma$ phase. Peak age hardening for the $\mathrm{X}_{0.5}$ and $\mathrm{X}_{1}$ alloys was observed at $500{ }^{\circ} \mathrm{C}$ because of the precipitation of the $\sigma$ phase and BCC phase, respectively.
\end{abstract}

Keywords: high-entropy alloy; microstructure; mechanical properties; age hardening

\section{Introduction}

The concept of "high-entropy alloys (HEA)", which was originally proposed Yeh et al. [1], provides an unresearched domain for the development of alloys. HEAs comprise 5 to 13 principal metallic elements, with the concentrations of each element being greater than 5 at.\%, and $\Delta S_{\text {conf }} \geq 1.5 \mathrm{R}$ [2]. From the very beginning, an AlCoCrCuFeNi system has been systematically investigated; this serves as a fundamental for future advances [3-12]. Due to the severe segregation of the Cu-rich FCC phase at the interdendrite, corrosion resistance decreases; as a result, the development of the AlCoCrFeNi system by the removal of $\mathrm{Cu}$ has been investigated [5,13]. The as-cast $\mathrm{AlCoCrFeNi}$ alloy exhibited a microstructure with a spinodal decomposition structure comprising an ordered BCC (B2) phase and a wall-shaped BCC (A2) phase [13]. Munitz et al. [14] revealed microstructure variations of the $\mathrm{AlCoCrFeNi}$ alloy after heat treatment. The as-cast alloy exhibited a dendritic morphology with a spinodal decomposition (B2 + A2) structure in the dendrite and interdendrite. The as-cast structure with the dendritic morphology did not change with heat treatment. However, different phase transformations occurred after heat treatment. Heat treatment between 650 and $975^{\circ} \mathrm{C}$ led to the transformation of the BCC phase to the $\sigma$ phase, resulting in a further increase in hardness. After heat treatment from 850 to $1100{ }^{\circ} \mathrm{C}$, the FCC phase was observed. Heat treatment at $1100{ }^{\circ} \mathrm{C}$ led to the transformation of the $\sigma$ phase to the BCC phase and softening of the alloy. Heat treatment at $1200{ }^{\circ} \mathrm{C}$ led to the dissolution of the FCC phase, thereby enabling the re-entry of the alloy into the miscibility gap and decomposition to a B2 matrix, with the precipitation of BCC in the dendrite core and interdendritic regions. Moreover, because of the excellent compressive properties of the $\mathrm{AlCoCrFeNi}$ alloy, including a yield stress of $1251 \mathrm{MPa}$, a compressive stress of $2004 \mathrm{MPa}$, and a fracture strain of $32.7 \%$, it demonstrates immense potential for development into structural materials [15]. In addition, the multi-phase refining of the suction-cast $\mathrm{AlCoCr}$ FeNi alloy was proposed as a promising structural material with considerable ductility 
without the considerable expense of strength by feasible thermomechanical processing [16]. The wear rate of the $\mathrm{AlCoCrFeNi}$ alloy is low under high load because of the high hardness of the B2 matrix, indicative of good wear resistance for this alloy and the possibility of developing a wear-resistant material [17]. Lu et al. [18] reported excellent oxidation resistance for the $\mathrm{AlCoCrFeNi}$ powder subjected to heat treatment at $900-1100{ }^{\circ} \mathrm{C}$, which is attributed to the formation of an exclusive $\mathrm{Al}_{2} \mathrm{O}_{3}$ scale and the inward oxygen diffusion mechanism; these results suggest that this alloy exhibits high-temperature resistance to oxidation.

Co is well known to be the most expensive element in the AlCoCrFeNi alloy, with the cost of Ni being one-third that of Co. Recently [19], with the decrease in the Co content of the AlCoCrFeNi alloy, the molar ratio of Co has decreased because of the improved compressive stress. However, the fracture strain is sacrificed because of the increase in the volume fraction of the BCC phase; this indicates that the reduction in cost only by decreasing the Co content causes alloy embrittlement. A previous study [20] has reported that $\mathrm{Ni}$ and $\mathrm{Co}$ are stronger FCC stabilizers in HEAs, with an FCC equivalent of $\mathrm{Ni}_{\mathrm{FCC}}=1.1 \mathrm{Co}_{\mathrm{FCC}}$. The replacement of $\mathrm{Co}$ with $\mathrm{Ni}$ in the $\mathrm{AlCoCrFeNi}$ alloy was proposed to not only effectively reduce cost but also maintain the B2 matrix of this alloy. Therefore, this study discusses the effects of replacing $\mathrm{Co}$ with $\mathrm{Ni}$ on the microstructure, mechanical properties, and age hardening of $\mathrm{AlCo}_{1-x} \mathrm{CrFeNi}_{1+x}$ high-entropy alloys.

\section{Materials and Methods}

Three high-entropy alloys of $\mathrm{AlCo}_{1-x} \mathrm{CrFeNi}_{1+x}$ ( $\mathrm{x}$ is the molar ratio; $\mathrm{x}=0,0.5,1$, denoted as $\mathrm{X}_{0}, \mathrm{X}_{0.5}$, and $\mathrm{X}_{1}$, respectively) were synthesized by vacuum induction melting under argon, followed by casting in a ceramic shell mold. Commercial-grade elements of $\mathrm{Al}, \mathrm{Co}, \mathrm{Cr}, \mathrm{Fe}$, and $\mathrm{Ni}$ (99.5\% purity) were used as raw materials. Table 1 lists the chemical compositions of the three alloys. The dimensions of the ingots were $58 \times 58 \times 118 \mathrm{~mm}^{3}$. They were cut into flakes with dimensions of $10 \times 10 \times 2 \mathrm{~mm}^{3}$ to investigate the crystal structure, microstructure, and hardness before and after aging. Flakes of the same size were subjected to aging at 500 to $1100^{\circ} \mathrm{C}$, with a temperature gap of $100{ }^{\circ} \mathrm{C}$, and aging was conducted for $144 \mathrm{~h}$, followed by water quenching. The crystal structure was examined by X-ray diffraction (XRD; D2 Phaser, Bruker, Billerica, MA, USA) using $\mathrm{Cu} \mathrm{K}_{\alpha}$ radiation at a scanning rate of $2^{\circ} / \mathrm{min}$ and a $2 \theta$ range of $20-100^{\circ}$. The microstructure was observed by scanning electron microscopy (SEM; S3400N, Hitachi High-Tech Corporation, Tokyo, Japan) and transmission electron microscopy (TEM; Tecnai ${ }^{\text {TM }}$ G2 F20, FEI Technologies Inc., Hillsboro, OR, USA). Samples for SEM examination were polished by using an $\mathrm{Al}_{2} \mathrm{O}_{3}$ suspension, followed by etching using aqua regia. The thin-foil TEM sample was prepared by twin-jet electropolishing using 5\% perchloric acid for further TEM analysis. The chemical composition of the alloys and different phases in the alloy were determined by energy-dispersive spectrometry (EDS; XFlash ${ }^{\circledR}$ 6|100, Bruker, Billerica, MA, USA; Oxford X-Max 80, Oxford Instruments, Abingdon, UK). The volume fraction of each phase in the as-cast alloys was calculated with the image analysis software (MDS-Pro, FIRST OPTO-TECHNOLOGY CO., Kaohsiung, Taiwan). The Vickers hardness tester (FM-300e, Future-Tech Corp., Kawasaki, Japan) was used to measure hardness under a load of $1 \mathrm{~kg}$ for a duration of $15 \mathrm{~s}$. Ten locations were measured to calculate the average hardness and standard deviation. Compression tests were conducted by using a universal tester (CY-6040A4, Chun-Yen Testing Machines Co., Taichung, Taiwan) under a strain rate of $10^{-3} \mathrm{~s}^{-1}$. For the compression test, the specimen size was $\phi 5 \times 10 \mathrm{~mm}^{2}$.

Table 1. Chemical composition (at.\%) of the $\mathrm{X}_{0}, \mathrm{X}_{0.5}$, and $\mathrm{X}_{1}$ alloys.

\begin{tabular}{cccccc}
\hline Alloy & Al & Co & Cr & Fe & Ni \\
\hline $\mathrm{X}_{0}$ & 21.1 & 21.2 & 18.7 & 18.7 & 20.3 \\
$\mathrm{X}_{0.5}$ & 20.6 & 11.2 & 18.8 & 18.8 & 30.6 \\
$\mathrm{X}_{1}$ & 22.3 & N/A & 18.0 & 19.2 & 40.5 \\
\hline
\end{tabular}




\section{Results and Discussion}

\subsection{The As-Cast Alloys}

\subsubsection{Crystal Structure}

Figure 1 shows $\mathrm{XRD}$ patterns of the $\mathrm{X}_{0}, \mathrm{X}_{0.5}$, and $\mathrm{X}_{1}$ as-cast alloys. Two phases were identified in the as-cast alloys, i.e., BCC $(\mathrm{a}=2.865 \AA)$ and FCC $(\mathrm{a}=3.579 \AA)$ phases. The $B C C$ and FCC volume fractions were quantified by XRD with $\mathrm{Cu} \mathrm{K}_{\alpha}$ radiation via direct comparison [21], which uses the integration of the most intense peaks for the BCC phase (characterized by the (110), (200), (211), and (220) planes) and FCC phase (characterized by the (111), (200), (220), and (311) planes). Origin ${ }^{\mathrm{TM}}$ software was used for integrating these peaks with a peak-fitting tool. The volume fractions of the FCC phase for $\mathrm{X}_{0}, \mathrm{X}_{0.5}$, and $X_{1}$ alloys were $7.7,23.0$, and $31.9 \%$, respectively, indicating that compared with $\mathrm{Co}_{0}, \mathrm{Ni}$ is a stronger FCC stabilizer. The FCC phase detected for the as-cast $X_{0}$ alloy is speculative, because the cooling rate $\left(10^{-1}\right.$ to $\left.10^{-2} \mathrm{~K} / \mathrm{s}\right)$ of the melt in the ceramic shell mold by vacuum induction melting is lower than that $(10-20 \mathrm{~K} / \mathrm{s})$ of the water-cooled copper mold by vacuum arc re-melting, as reported in previous studies [3-14]. The fact that the FCC phase of as-cast $\mathrm{AlCoCrFeNi}$ is formed after homogenization at $1100{ }^{\circ} \mathrm{C}$ [13] confirms this hypothesis.

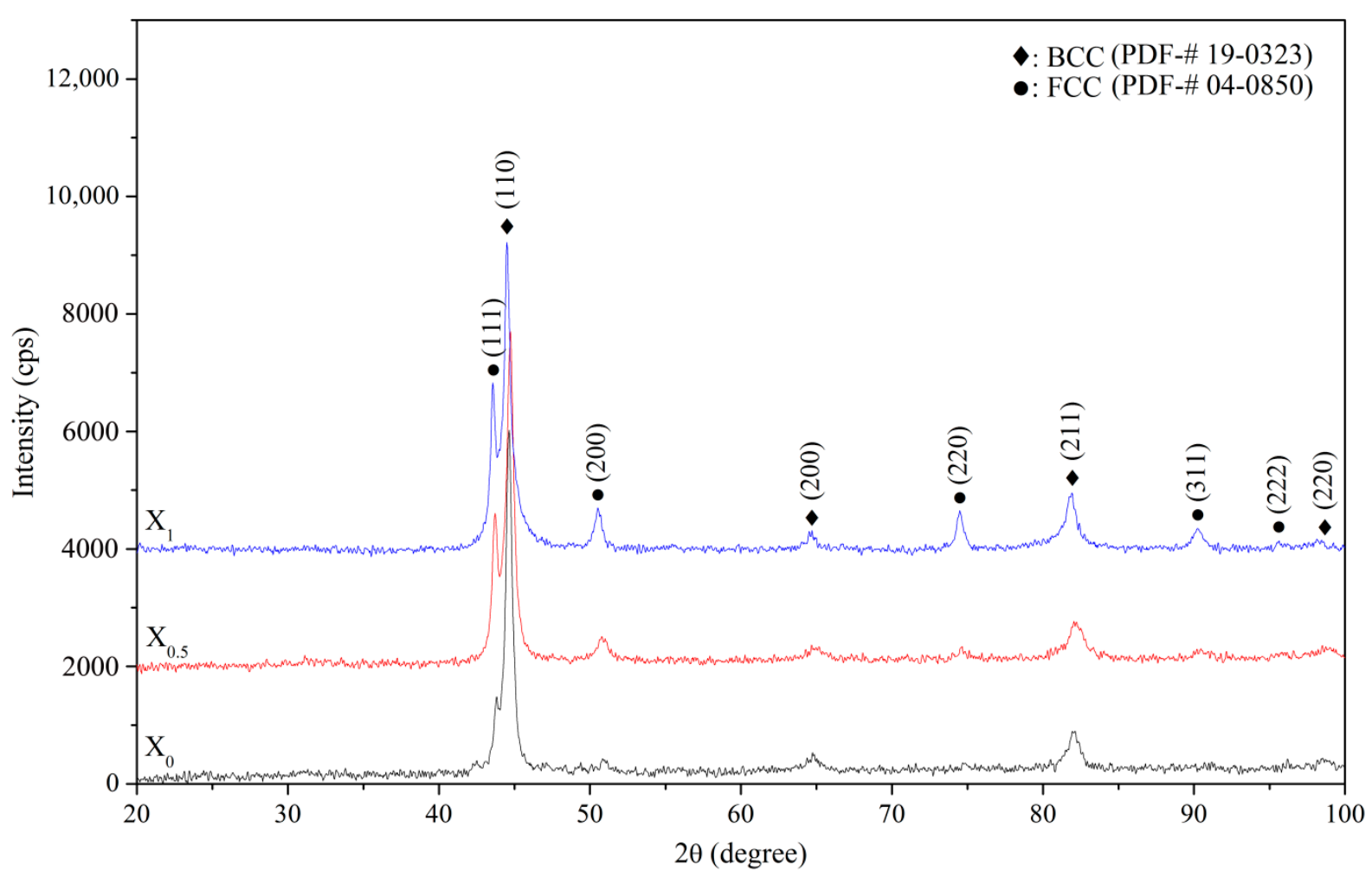

Figure 1. $X R D$ patterns of the $X_{0}, X_{0.5}$, and $X_{1}$ as-cast alloys.

\subsubsection{Microstructure}

Figure 2 shows SEM-backscattered electron (BSE) images of the $X_{0}$ as-cast alloy. Table 2 lists the chemical composition and volume fraction of the interior phases in Figure 2, as analyzed by EDS and image analysis, respectively. The low-magnification image shown in Figure 2a reveals the dendrite cell structure of the $X_{0}$ as-cast alloy, with a cell size of $100-250 \mu \mathrm{m}$. Figure $2 \mathrm{~b}$ shows the high-magnification image of the dendrite region, which has a spinodal decomposition (SD) structure comprising a dark-gray (Ni,Al)-rich matrix + light-gray wall-shaped $(\mathrm{Cr}, \mathrm{Fe})$-rich phase [13], as well as a bright wall-shaped $(\mathrm{Fe}, \mathrm{Cr}, \mathrm{Co})$-rich phase. The interdendrite region comprises a dark-gray $(\mathrm{Ni}, \mathrm{Al})$-rich matrix and a bright boundary-like ( $\mathrm{Fe}, \mathrm{Cr}, \mathrm{Co}$ )-rich phase (Figure 2c). 


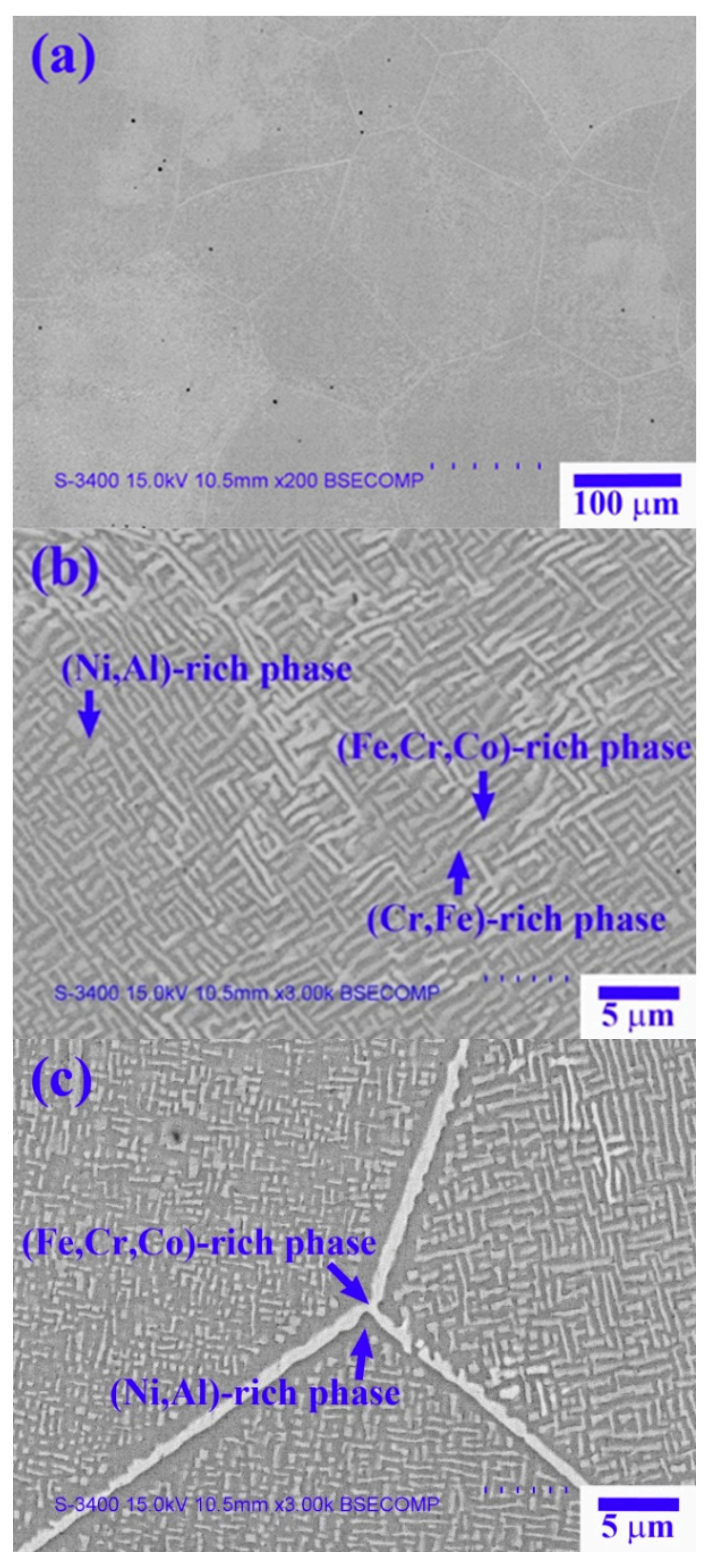

Figure 2. SEM-BSE images of the $\mathrm{X}_{0}$ as-cast alloy: (a) low magnification; (b) high magnification of dendrite; and (c) high magnification of interdendrite.

Table 2. Chemical composition (at.\%) and volume fraction (\%) of the interior phases marked in Figure 2.

\begin{tabular}{ccccccc}
\hline Phase & Volume Fraction & Al & Co & Cr & Fe & Ni \\
\hline (Ni,Al)-rich phase & $62.7 \pm 2.1$ & $31.2 \pm 2.8$ & $20.4 \pm 1.6$ & $8.2 \pm 0.9$ & $13.6 \pm 1.7$ & $26.6 \pm 1.1$ \\
(Cr,Fe)-rich phase & $27.2 \pm 2.3$ & $11.5 \pm 2.0$ & $19.3 \pm 1.1$ & $35.8 \pm 2.5$ & $23.6 \pm 1.3$ & $9.8 \pm 0.6$ \\
$(\mathrm{Fe}, \mathrm{Cr}, \mathrm{Co})$-rich phase & $10.1 \pm 1.1$ & $7.4 \pm 1.1$ & $25.4 \pm 1.5$ & $25.2 \pm 2.3$ & $26.8 \pm 1.4$ & $15.2 \pm 1.8$ \\
\hline
\end{tabular}

Figures 3 and 4 show TEM bright-field images and selected-area electron diffraction (SAED) patterns of the dendrite and interdendrite in the $\mathrm{X}_{0}$ alloy, respectively. Table 3 lists chemical compositions of the interior phases marked in Figures 3 and 4. The SAED and EDS analysis revealed the presence of the dark-gray $(\mathrm{Al}, \mathrm{Ni})$-rich ordered $\mathrm{BCC}(\mathrm{B} 2)$ phase, light-gray wall-shaped $(\mathrm{Cr}, \mathrm{Fe})$-rich $\mathrm{BCC}$ phase, and bright, wall-shaped $(\mathrm{Fe}, \mathrm{Cr}, \mathrm{Co})$-rich FCC phase (Figures 3 and 4). Notably, in the dendrite region, the BCC (yellow dot) and FCC (blue dot) phases formed in one wall-shaped structure (Figure 3), indicating that the 
FCC phase transformed from the BCC phase because both phases are rich in $\mathrm{Fe}, \mathrm{Cr}$, and $\mathrm{Co}$, and are deficient in $\mathrm{Ni}$ and $\mathrm{Al}$.

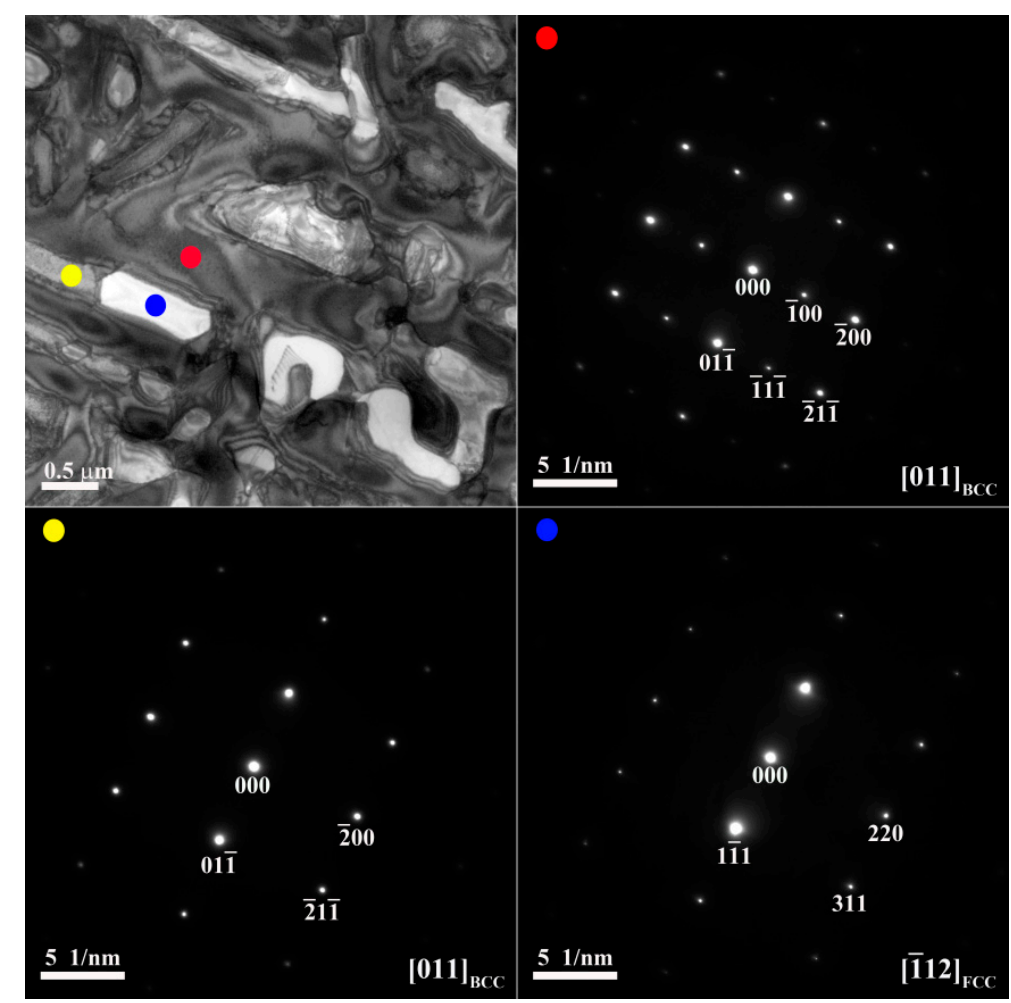

Figure 3. TEM bright-field images and SAED patterns of the dendrite for the $\mathrm{X}_{0}$ as-cast alloy (red dot: ordered BCC; yellow dot: BCC; blue dot: FCC).
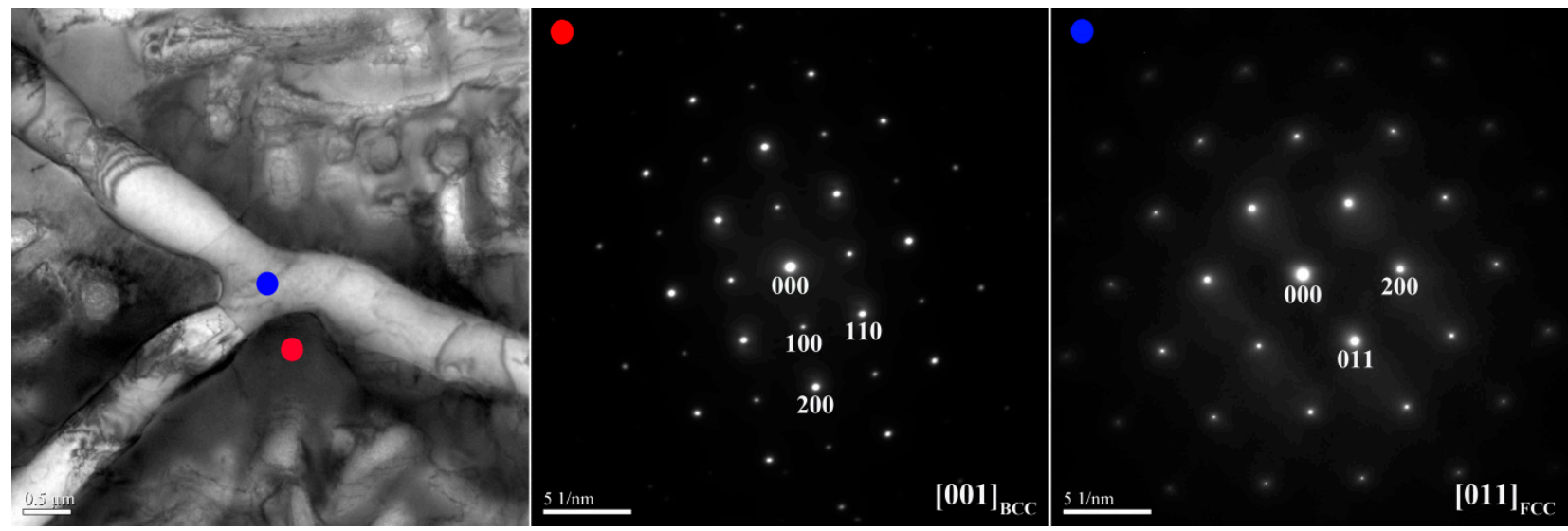

Figure 4. TEM bright-field images and SAED patterns of the interdendrite for the $\mathrm{X}_{0}$ as-cast alloy (red dot: ordered BCC; blue dot: FCC).

Figure 5 shows SEM-BSE images of the $\mathrm{X}_{0.5}$ as-cast alloy, and Table 4 lists the chemical composition and volume fraction of the interior phases. Figure 5 a shows the microstructure of the $X_{0.5}$ as-cast alloy: a dendritic cell structure with a cell size of $120-300 \mu \mathrm{m}$ is observed. The high-magnification image shown in Figure $5 b$ of the dendrite region indicated that it was constructed by an SD structure (dark-gray (Ni,Al)-rich B2 matrix + light-gray wallshaped or spherical ( $\mathrm{Cr}, \mathrm{Fe})$-rich BCC phase) and a bright rod-like (Fe,Cr,Ni)-rich FCC phase. The interdendrite region comprises the dark-gray ( $\mathrm{Ni}, \mathrm{Al}$ )-rich B2 matrix and a bright boundary-like (Fe,Cr,Ni)-rich FCC phase (Figure 5b). Compared with the $\mathrm{X}_{0}$ ascast alloy, the wall-shaped BCC phase exhibits spheroidization in the center region of 
the dendrite, and the FCC phase coarsens to a rod-like structure. In the interdendrite, the FCC phase is branched into the dendrite region. In addition, the replacement of Co with Ni permits the transformation of the $(\mathrm{Fe}, \mathrm{Cr}, \mathrm{Co})$-rich $\mathrm{FCC}$ phase in the $\mathrm{X}_{0}$ alloy to the $(\mathrm{Fe}, \mathrm{Cr}, \mathrm{Ni})$-rich phase in the $\mathrm{X}_{0.5}$ alloy.

Table 3. Chemical composition (at.\%) of the interior phases marked in Figures 3 and 4.

\begin{tabular}{ccccccc}
\hline Region & Phase & Al & Co & Cr & Fe & Ni \\
\hline Dendrite & B2 & $24.7 \pm 1.9$ & $21.8 \pm 0.5$ & $6.0 \pm 1.3$ & $15.9 \pm 1.4$ & $31.6 \pm 2.3$ \\
& BCC & $2.3 \pm 1.1$ & $15.9 \pm 1.1$ & $49.4 \pm 3.9$ & $27.2 \pm 1.1$ & $5.2 \pm 0.4$ \\
& FCC & $3.2 \pm 1.4$ & $26.4 \pm 1.2$ & $27.0 \pm 1.5$ & $31.0 \pm 1.2$ & $12.4 \pm 1.6$ \\
Interdendrite & B2 & $24.5 \pm 1.8$ & $21.5 \pm 1.6$ & $7.0 \pm 0.3$ & $15.0 \pm 1.7$ & $32.0 \pm 1.9$ \\
& FCC & $3.8 \pm 1.7$ & $24.6 \pm 1.2$ & $28.6 \pm 1.4$ & $29.6 \pm 1.5$ & $13.4 \pm 1.1$ \\
\hline
\end{tabular}
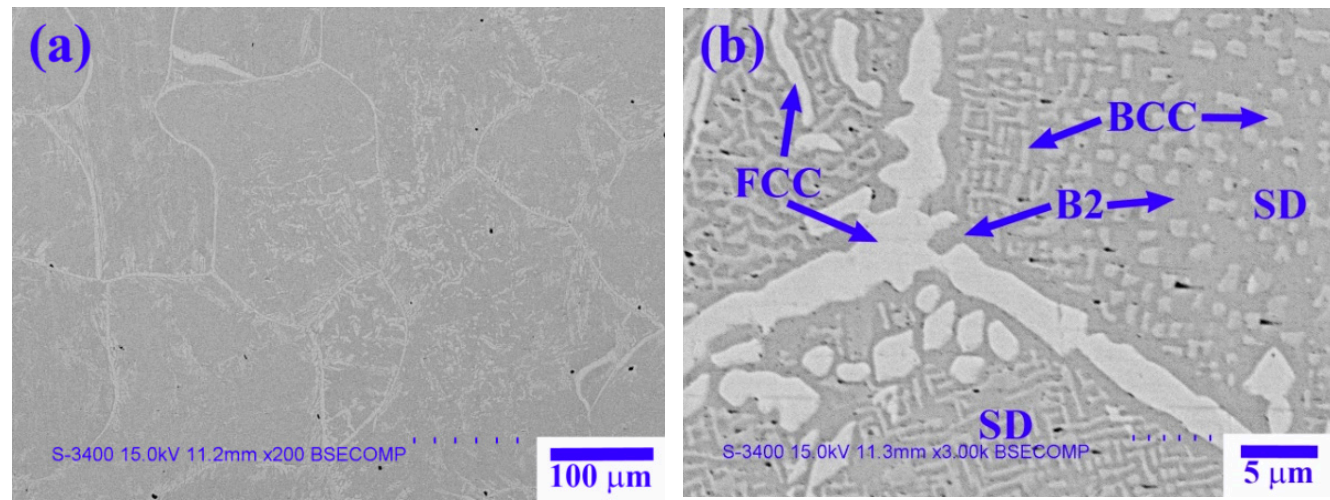

Figure 5. SEM-BSE images of the $\mathrm{X}_{0.5}$ as-cast alloy: (a) low magnification; (b) high magnification.

Table 4. Chemical composition (at.\%) and volume fraction (\%) of the interior phases marked in Figure 5.

\begin{tabular}{ccccccc}
\hline Phase & Volume Fraction & Al & Co & Cr & Fe & Ni \\
\hline B2 & $52.6 \pm 2.1$ & $33.8 \pm 2.7$ & $9.7 \pm 0.8$ & $5.5 \pm 1.0$ & $12.2 \pm 1.4$ & $38.8 \pm 3.1$ \\
BCC & $24.1 \pm 1.7$ & $1.4 \pm 0.6$ & $13.1 \pm 1.5$ & $47.3 \pm 1.9$ & $30.7 \pm 1.9$ & $7.5 \pm 0.4$ \\
FCC & $23.3 \pm 1.4$ & $7.9 \pm 1.9$ & $14.1 \pm 1.1$ & $26.0 \pm 1.7$ & $27.6 \pm 1.4$ & $24.4 \pm 1.6$ \\
\hline
\end{tabular}

Figures 6 and 7 show TEM bright-field images and SAED patterns of the $X_{0.5}$ as-cast alloy, respectively. Table 5 lists the chemical composition of interior phases marked in Figures 6 and 7. Figure 6 shows the SD structure in the center region of the dendrite. This structure is a combination of the $(\mathrm{Ni}, \mathrm{Al})$-rich $\mathrm{B} 2$ matrix and $(\mathrm{Cr}, \mathrm{Fe})$-rich $\mathrm{BCC}$ phase. Figure 7 shows the assembly of the interdendrite by the (Ni,Al)-rich $\mathrm{B} 2$ matrix and the (Fe,Cr,Ni)-rich FCC phase.

Table 5. Chemical composition (at.\%) of the interior phases marked in Figures 6 and 7.

\begin{tabular}{ccccccc}
\hline Region & Phase & Al & Co & Cr & Fe & Ni \\
\hline Dendrite & B2 & $34.3 \pm 2.1$ & $8.7 \pm 1.5$ & $2.8 \pm 1.0$ & $11.9 \pm 1.7$ & $42.3 \pm 3.4$ \\
& BCC & $1.0 \pm 0.7$ & $10.3 \pm 1.4$ & $53.1 \pm 2.5$ & $30.8 \pm 1.6$ & $4.8 \pm 1.4$ \\
Interdendrite & B2 & $33.1 \pm 2.6$ & $8.8 \pm 1.6$ & $3.4 \pm 0.4$ & $11.2 \pm 0.8$ & $43.5 \pm 2.2$ \\
& FCC & $5.7 \pm 1.1$ & $12.9 \pm 1.8$ & $28.9 \pm 1.9$ & $30.2 \pm 2.3$ & $22.3 \pm 1.3$ \\
\hline
\end{tabular}




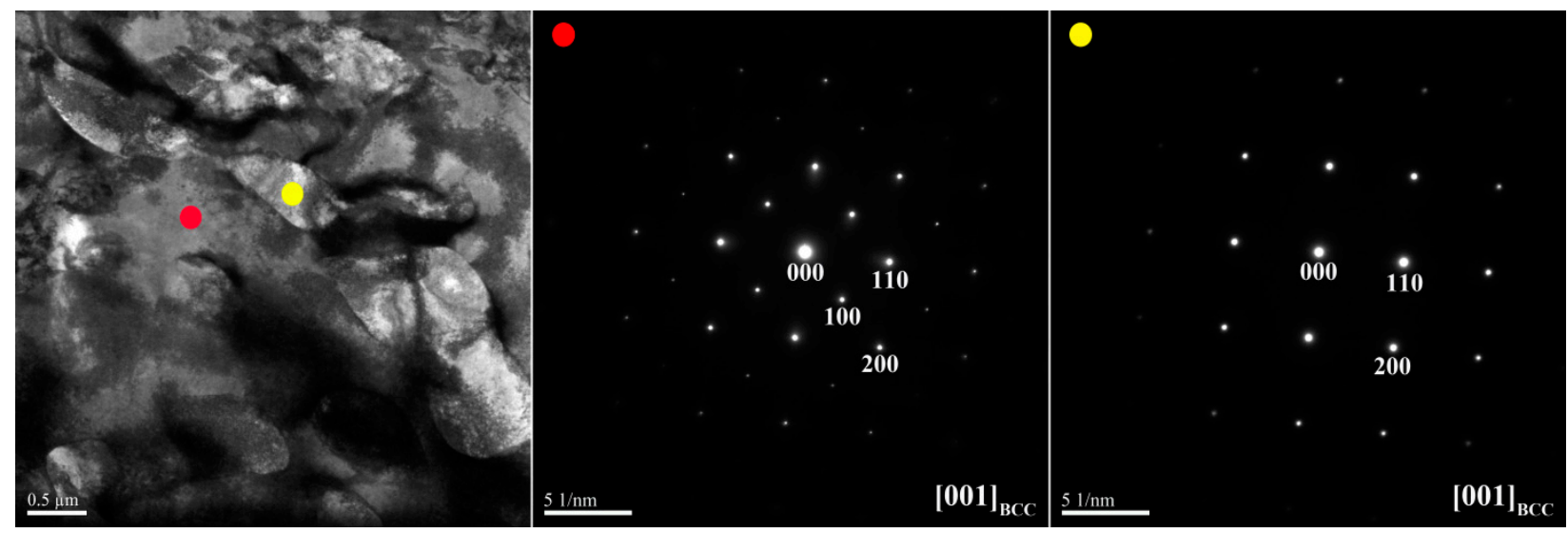

Figure 6. TEM bright-field image and SAED patterns of the dendrite for the $\mathrm{X}_{0.5}$ as-cast alloy (red dot: ordered BCC; yellow dot: BCC).

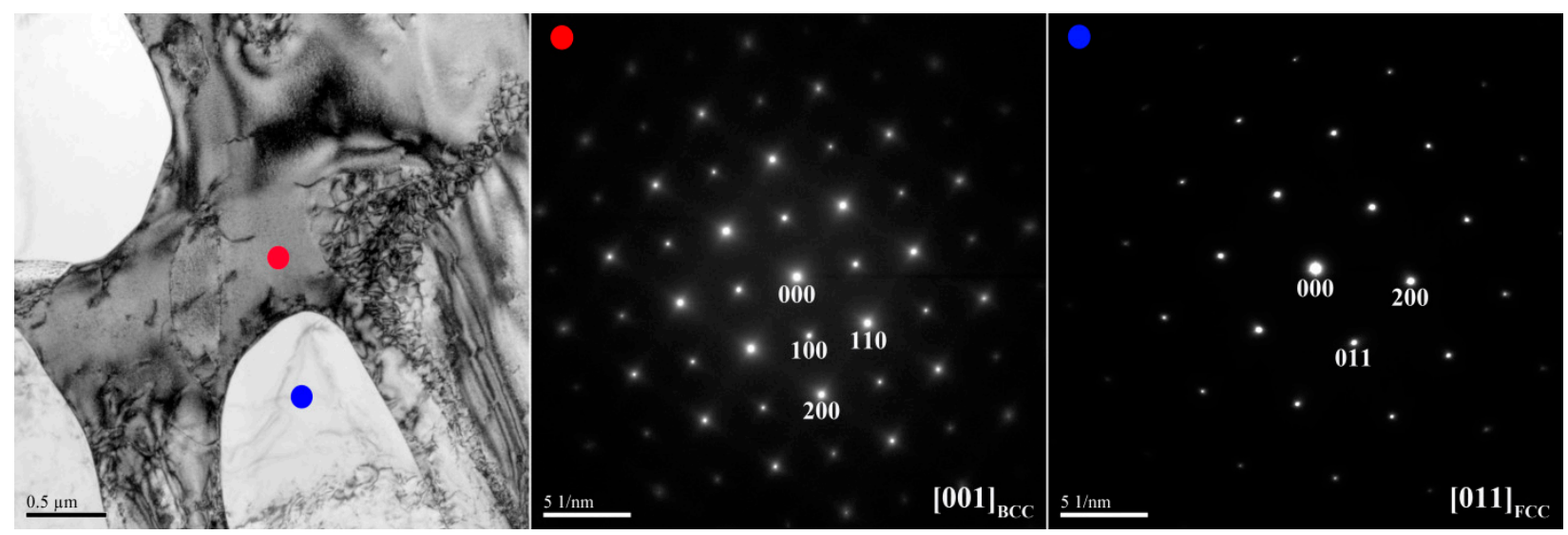

Figure 7. TEM bright-field image and SAED patterns of the interdendrite for the $\mathrm{X}_{0.5}$ as-cast alloy (red dot: ordered BCC; blue dot: FCC).

Figure 8 shows the microstructure of the $X_{1}$ as-cast alloy, and Table 6 lists the chemical composition and volume fraction of the interior phases marked in Figure 8 . The $X_{1}$ as-cast alloy exhibited a dendritic structure (Figure 8a). The high-magnification image of the SD structure shown in Figure $8 \mathrm{~b}$ reveals a dendrite region (DR) comprising a dark-gray (Ni,Al)-rich B2 matrix and a light-gray spherical $(\mathrm{Cr}, \mathrm{Fe})$-rich $\mathrm{BCC}$ phase. The interdendrite (ID) region comprises a lamellar (Ni,Fe,Cr)-rich FCC phase and an SD structure between the FCC phase. Figures 9 and 10 show TEM bright-field images and SAED patterns, respectively, of the $X_{1}$ as-cast alloy. Table 7 lists chemical composition of the interior phases marked in Figures 9 and 10. The SAED patterns and EDS results shown in Figures 9 and 10 confirm that the dendrite comprises (Ni,Al)-rich B2 and $(\mathrm{Cr}, \mathrm{Fe})$-rich BCC phases. The interdendrite comprises (Ni,Al)-rich B2 and (Ni,Fe,Cr)-rich FCC phases.

Table 6. Chemical composition (at.\%) and volume fraction (\%) of the interior phases marked in Figure 8 .

\begin{tabular}{ccccccc}
\hline Phase & $\begin{array}{c}\text { Volume } \\
\text { Fraction }\end{array}$ & Al & Co & Cr & Fe & Ni \\
\hline B2 & $49.0 \pm 2.3$ & $34.5 \pm 2.3$ & N/A & $4.6 \pm 0.8$ & $11.2 \pm 0.6$ & $49.7 \pm 2.7$ \\
BCC & $18.2 \pm 1.5$ & $4.5 \pm 0.6$ & N/A & $45.4 \pm 2.1$ & $30.5 \pm 2.3$ & $19.6 \pm 1.9$ \\
FCC & $32.8 \pm 1.9$ & $7.5 \pm 1.2$ & N/A & $27.5 \pm 1.6$ & $30.4 \pm 1.5$ & $34.6 \pm 2.1$ \\
\hline
\end{tabular}



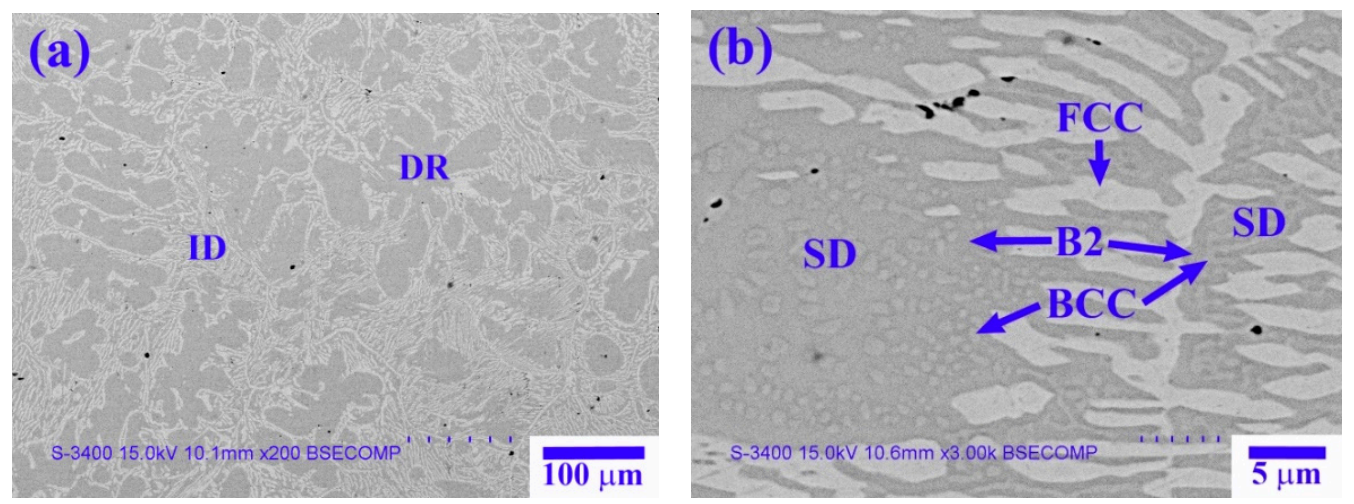

Figure 8. SEM-BSE images of the $X_{1}$ as-cast alloy: (a) low magnification; (b) high magnification.

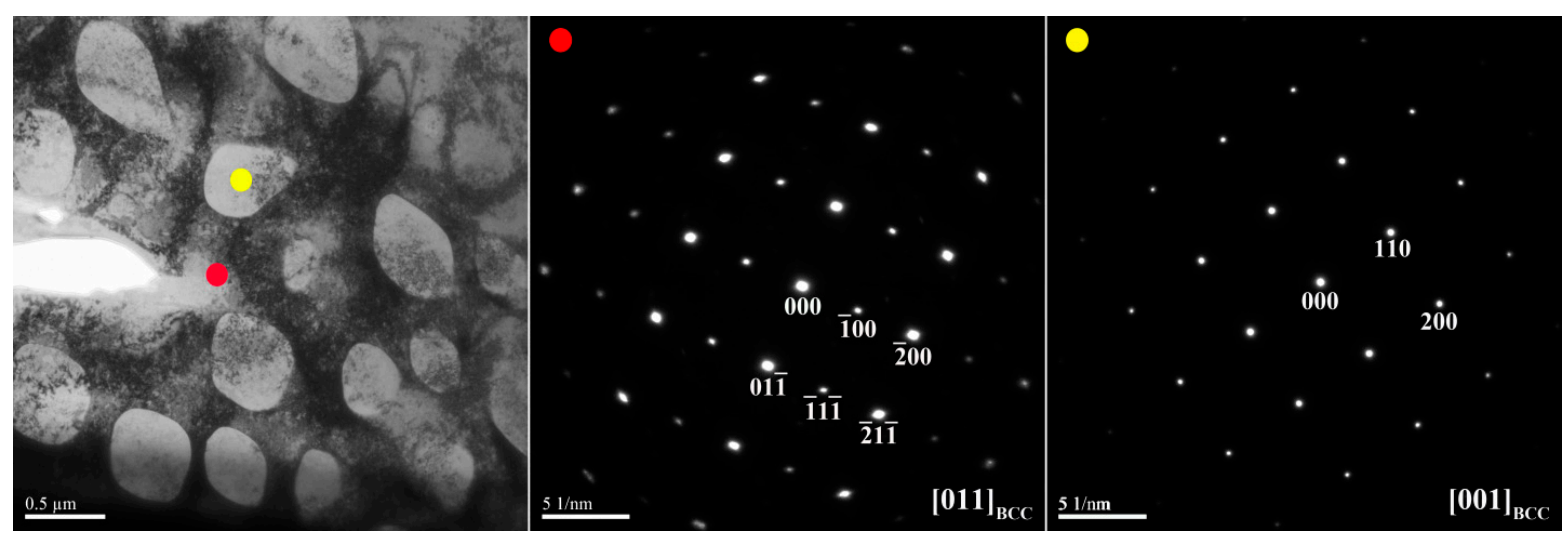

Figure 9. TEM bright-field image and SAED patterns of dendrite for the $\mathrm{X}_{1}$ as-cast alloy (red dot: ordered BCC; yellow dot: $B C C)$.

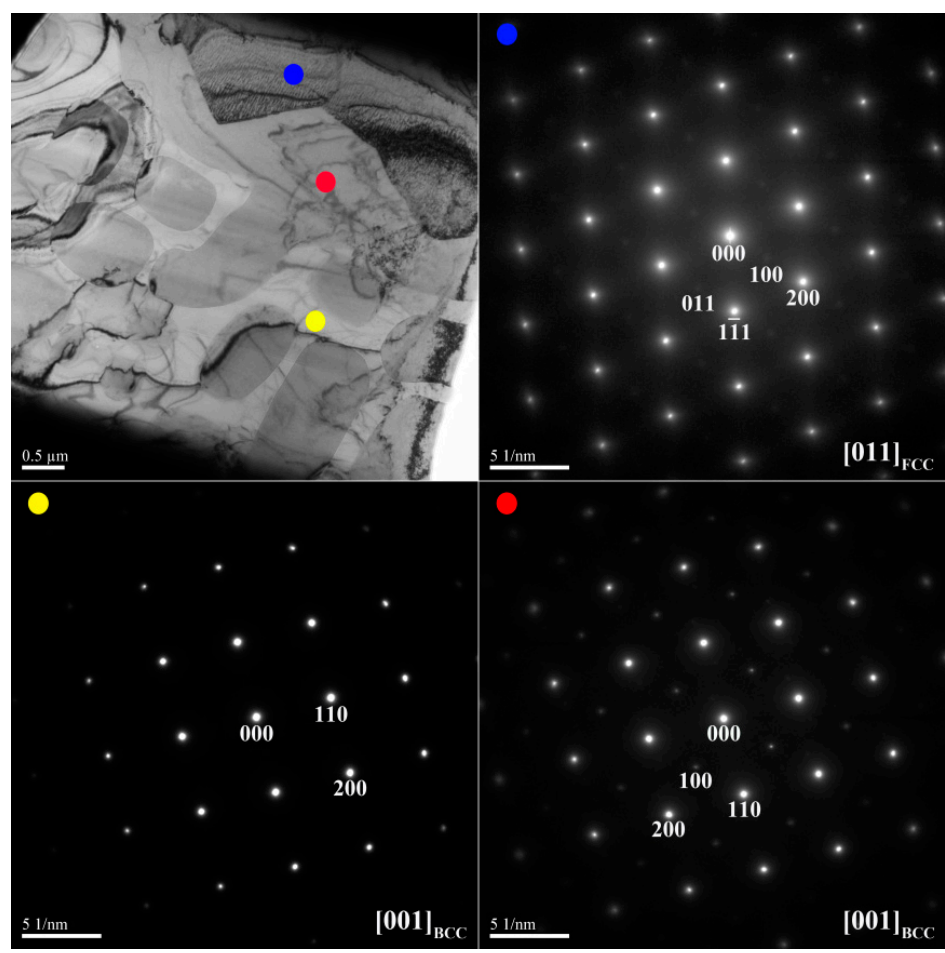

Figure 10. TEM bright-field image and SAED patterns of the interdendrite for the $\mathrm{X}_{1}$ as-cast alloy (red dot: ordered BCC; yellow dot: BCC; blue dot: FCC). 
Table 7. Chemical composition (at.\%) of the interior phases marked in Figures 9 and 10.

\begin{tabular}{ccccccc}
\hline Region & Phase & Al & Co & Cr & Fe & Ni \\
\hline Dendrite & B2 & $33.9 \pm 2.4$ & N/A & $3.0 \pm 0.5$ & $10.3 \pm 0.7$ & $52.8 \pm 2.5$ \\
& BCC & $0.9 \pm 0.4$ & N/A & $63.0 \pm 2.7$ & $30.2 \pm 1.1$ & $5.9 \pm 1.0$ \\
Interdendrite & B2 & $33.5 \pm 1.5$ & N/A & $2.8 \pm 0.6$ & $11.6 \pm 1.2$ & $52.1 \pm 2.2$ \\
& BCC & $0.9 \pm 0.7$ & N/A & $62.3 \pm 2.4$ & $30.3 \pm 1.4$ & $6.5 \pm 1.2$ \\
& FCC & $7.0 \pm 1.3$ & N/A & $28.4 \pm 1.6$ & $30.3 \pm 1.9$ & $34.3 \pm 1.8$ \\
\hline
\end{tabular}

Comparison of the $X_{0.5}$ and $X_{1}$ as-cast alloys revealed that the chemical composition of the FCC phase in the interdendrite transformed from the $(\mathrm{Fe}, \mathrm{Cr}, \mathrm{Ni})$-rich phase in the $\mathrm{X}_{0.5}$ alloy to the $(\mathrm{Ni}, \mathrm{Fe}, \mathrm{Cr})$-rich phase in the $\mathrm{X}_{1}$ alloy because of the complete substitution of Co with Ni. Furthermore, the SAED pattern of the (Ni,Fe,Cr)-rich FCC phase shown in Figure 10 reveals an ordered phase. With respect to the phase transformation theory [22], in systems with strong chemical bonding between the atoms, ordered phases tend to be formed. The negative mixing enthalpy $\left(\Delta \mathrm{H}_{\text {mix }}\right)$ between $\mathrm{Ni}$ and the other constitutional elements is thought to increase in comparison with that between those elements and $\mathrm{Co}$ [23]; hence, the number of stronger $\mathrm{Ni}-\mathrm{Al}, \mathrm{Ni}-\mathrm{Cr}$, and $\mathrm{Ni}-\mathrm{Fe}$ bonds increases, also further increasing with the substitution of $\mathrm{Co}$ with $\mathrm{Ni}$ in the alloy. Hence, the $\mathrm{X}_{1}$ alloy exhibited an ordered FCC phase. The volume fractions of the FCC phase in $X_{0}, X_{0.5}$, and $X_{1}$ alloys calculated by image analysis were close to the results calculated by XRD peaks.

\subsubsection{Mechanical Properties}

Figure 11 shows variations in the hardness and FCC phase volume fraction for the $\mathrm{X}_{0}$, $\mathrm{X}_{0.5}$, and $\mathrm{X}_{1}$ as-cast alloys. From the substitution of $\mathrm{Co}$ with $\mathrm{Ni}$, the hardness decreased by $25 \%$ from HV480 to HV360. Meanwhile, the FCC phase volume fraction increased from 7.7 to $31.9 \%$. The decrease in the hardness was caused by the increase in the volume fraction of the soft FCC phase. From a previous report [13], the hardness of as-cast AlCoCrFeNi alloy is HV484, which is close to the present $X_{0}$ alloy. Figure 12 shows compressive true stress-strain curves of the $X_{0}, X_{0.5}$, and $X_{1}$ as-cast alloys, and Table 8 lists yield stress $\left(\sigma_{\mathrm{y}}\right)$, compressive stress $\left(\sigma_{\max }\right)$, and fracture strain $\left(\varepsilon_{\mathrm{f}}\right)$ of the three alloys. From $\mathrm{X}_{0}$ to $\mathrm{X}_{1}$ alloys, the $\sigma_{\mathrm{y}}$ and $\sigma_{\max }$ decreased from 1202 and $1790 \mathrm{MPa}$ to 693 and $1537 \mathrm{MPa}$, respectively. However, $\varepsilon_{\mathrm{f}}$ increased from 0.15 to 0.42 . This result is also related to the increase in the amount of the soft FCC phase. Notably, from the $X_{0}$ to $X_{1}$ alloy, $\sigma_{\max }$ slightly decreased by $14 \%$, but $\varepsilon_{\mathrm{f}}$ considerably increased by $180 \%$, indicating that the substitution of Co with $\mathrm{Ni}$ can effectively improve the strength-ductility balance. Comparing the compressive properties of the $\mathrm{X}_{0}$ alloy with $\mathrm{AlCrFeCoNi}$ alloy mentioned in the Introduction, the $\mathrm{X}_{0}$ alloy exhibited lower $\sigma_{\max }$ and $\varepsilon_{\mathrm{f}}$. We suggest that the worse cleanliness of the present alloy synthesized by the vacuum induction melting process under $\mathrm{Al}_{2} \mathrm{O}_{3}$ crucible than previously published $\mathrm{AlCrFeCoNi}$ alloy [15] synthesized by vacuum arc re-melting process is the main reason.

Figure 13 shows SEM images of the fracture surfaces after compression. From the $\mathrm{X}_{0}$ to $X_{1}$ alloy, the amounts of the dimple structure clearly increase, indicative of the increase in the alloy ductility by the replacement of Co by Ni.

Table 8. Yield stress $\left(\sigma_{\mathrm{y}}\right)$, compressive stress $\left(\sigma_{\max }\right)$, and fracture strain $\left(\varepsilon_{\mathrm{f}}\right)$ of the $\mathrm{X}_{0}, \mathrm{X}_{0.5}$, and $\mathrm{X}_{1}$ as-cast alloys.

\begin{tabular}{cccc}
\hline Alloy & $\sigma_{\mathbf{y}}(\mathbf{M P a})$ & $\boldsymbol{\sigma}_{\max }(\mathbf{M P a})$ & $\varepsilon_{\mathbf{f}}$ \\
\hline $\mathrm{X}_{0}$ & 1202 & 1790 & 0.15 \\
$\mathrm{X}_{0.5}$ & 989 & 1644 & 0.33 \\
$\mathrm{X}_{1}$ & 653 & 1537 & 0.42 \\
\hline
\end{tabular}




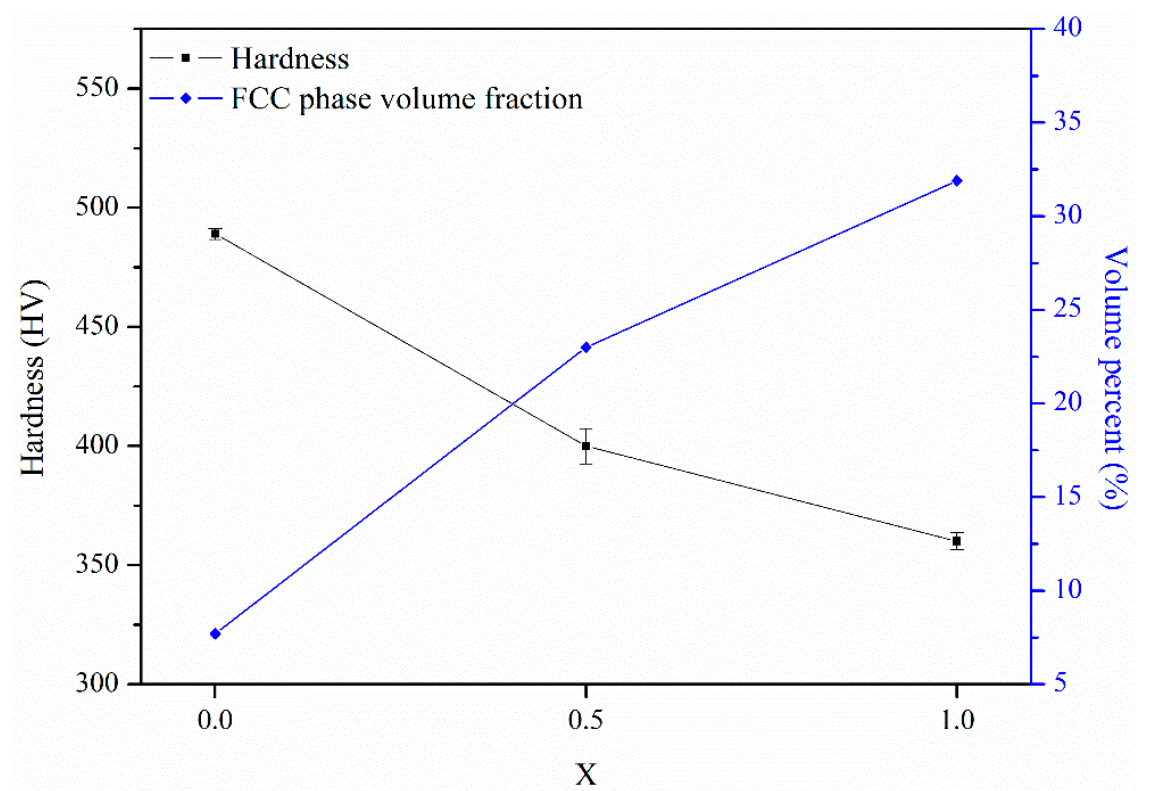

Figure 11. Variations in the hardness and FCC phase volume fraction of the $X_{0}, X_{0.5}$, and $X_{1}$ as-cast alloys.

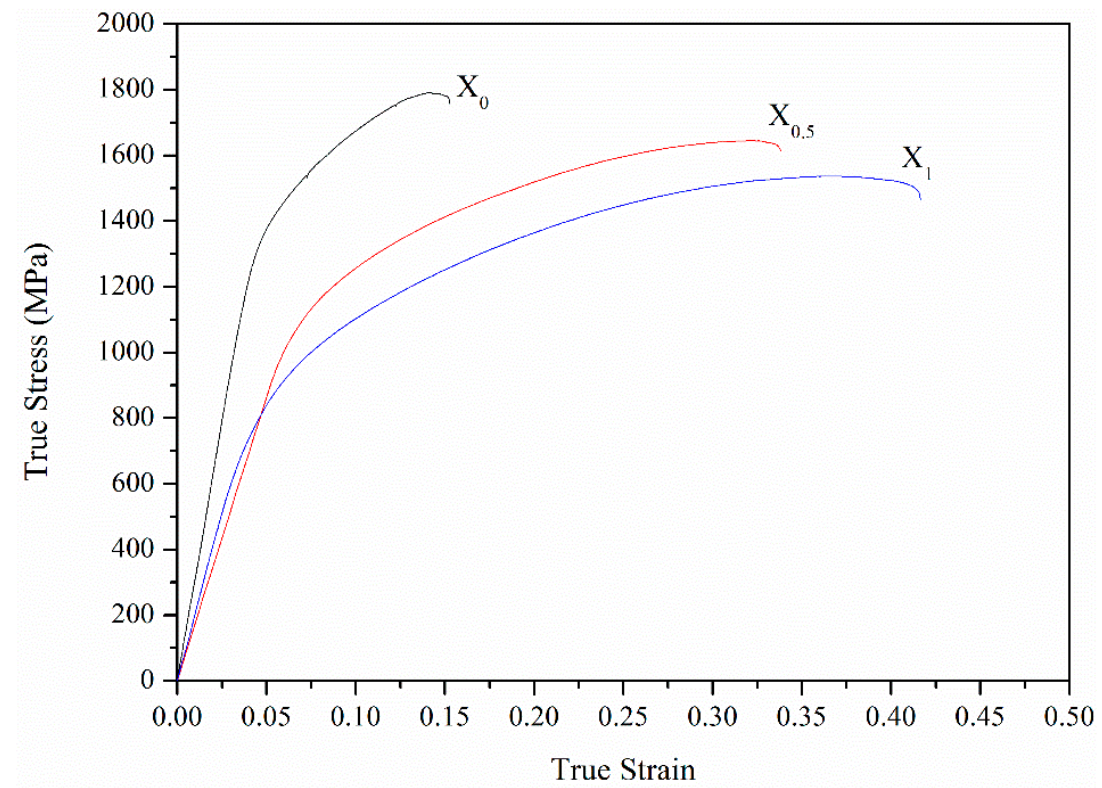

Figure 12. True stress-strain curves obtained from compression tests for the $X_{0}, X_{0.5}$, and $X_{1}$ as-cast alloys.

\subsection{The Aged Alloys}

3.2.1. Variations in Hardness and Crystal Structure

Figure 14 shows variations in the hardness for the $X_{0}, X_{0.5}$, and $X_{1}$ aged alloys at $500-1000{ }^{\circ} \mathrm{C}$. For the $\mathrm{X}_{0}$ alloy, with the increase in the aging temperature, the hardness increased from HV480 to a peak value of HV601 $\left(25 \%\right.$ increase) at $600{ }^{\circ} \mathrm{C}$, followed by a decrease with the increase in the aging temperature to the bottom value $\mathrm{HV} 371$ at $1000{ }^{\circ} \mathrm{C}$. The peak hardness with the increase in the aging temperature for the $\mathrm{X}_{0.5}$ and $\mathrm{X}_{1}$ alloys was observed at $500{ }^{\circ} \mathrm{C}$ for HV472 (18\% increase) and HV418 (16\% increase), respectively. At $600-1000{ }^{\circ} \mathrm{C}$, with the increase in the aging temperature, the hardness of the $\mathrm{X}_{0.5}$ and $X_{1}$ alloys decreased to the bottom values of HV318 and HV 320, respectively. The temperature ranges for age hardening for the $X_{0}, X_{0.5}$, and $X_{1}$ alloys were 500-800, 500-700, and $500-600{ }^{\circ} \mathrm{C}$, respectively. Moreover, age softening was observed at 900-1000, 800-1000, 
and $700-1000{ }^{\circ} \mathrm{C}$ for the $\mathrm{X}_{0}, \mathrm{X}_{0.5}$, and $\mathrm{X}_{1}$ alloys, respectively. The following crystal and microstructure analyses describe the aging behaviors.

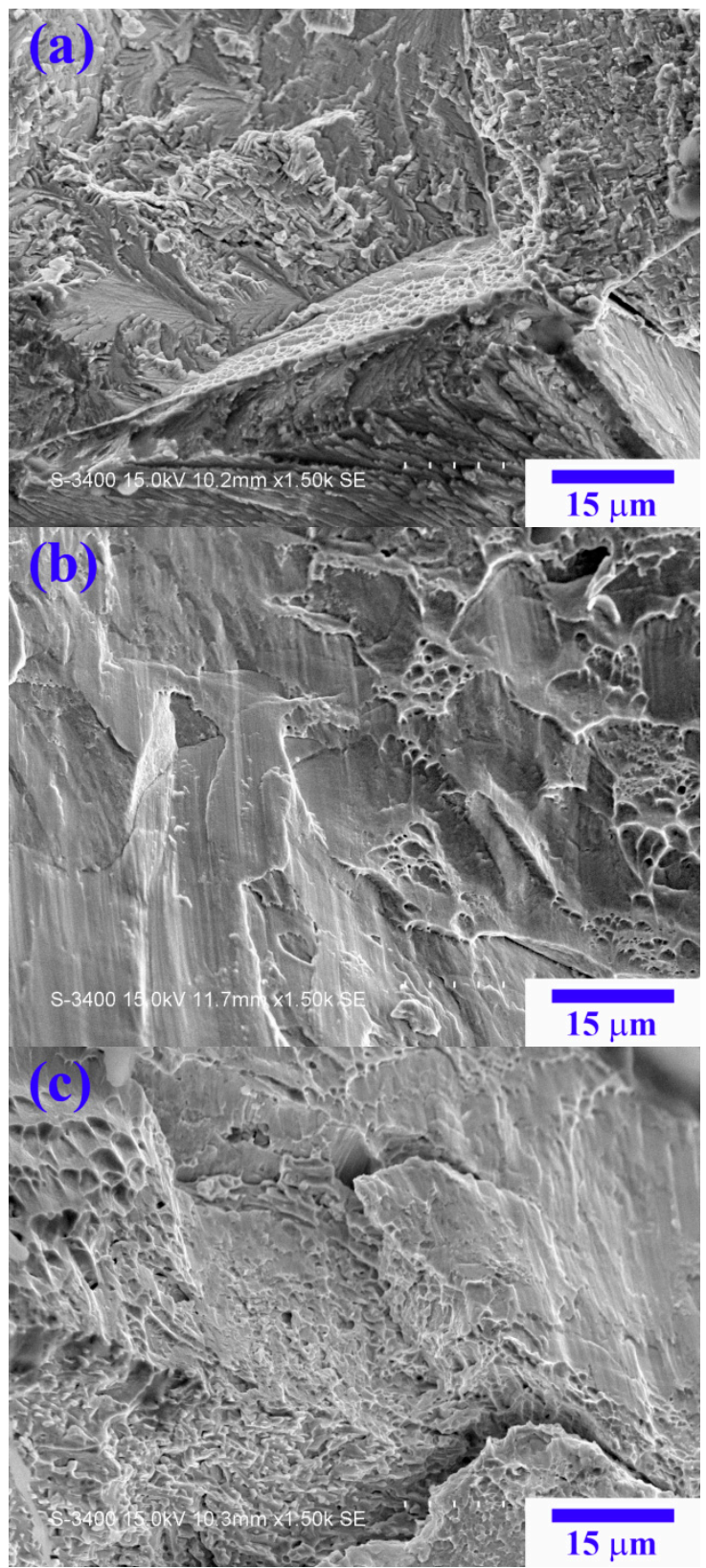

Figure 13. SEM images of fracture surfaces of the (a) $\mathrm{X}_{0} ;(\mathbf{b}) \mathrm{X}_{0.5}$; and (c) $\mathrm{X}_{1}$ alloys after compressive test.

Figure 15 shows XRD patterns of the three aged alloys. The three aged alloys were primarily composed of the $\mathrm{B} 2, \mathrm{BCC}$, and FCC phases. The $\mathrm{Cr}, \mathrm{Fe}-\mathrm{like} \sigma$ phase $\left(\mathrm{a}=8.800 \AA, \mathrm{c}=4.544 \AA, \mathrm{c} / \mathrm{a}=0.516\right.$, PDF-\# 05-0708) was identified in the $\mathrm{X}_{0}$ and $\mathrm{X}_{0.5}$ alloys at $500-900{ }^{\circ} \mathrm{C}$ and $500-800{ }^{\circ} \mathrm{C}$, respectively. For the $\mathrm{X}_{0}$ alloy, from the diffraction peak intensity, the volume fraction of the $\sigma$ phase increased with the increase in the temperature from 500 to $600{ }^{\circ} \mathrm{C}$ and decreased from 700 to $900{ }^{\circ} \mathrm{C}$ (Figure 15a). With the increase in temperature from 700 to $1000{ }^{\circ} \mathrm{C}$, the volume fraction of the FCC phase increases. The maximum amount of the $\sigma$ phase formed at $500{ }^{\circ} \mathrm{C}$ and decreased from 600 to $800{ }^{\circ} \mathrm{C}$ for the $\mathrm{X}_{0.5}$ alloy (Figure $15 \mathrm{~b}$ ). Similar to the $\mathrm{X}_{0}$ alloy, the volume fraction of the FCC phase increased with the increase in temperature from 700 to $1000{ }^{\circ} \mathrm{C}$. The maximum amount of the BCC phase was generated at $500{ }^{\circ} \mathrm{C}$ for the $\mathrm{X}_{1}$ alloy (Figure $15 \mathrm{c}$ ). The variation 
in the FCC phase for the $X_{1}$ alloy was similar to that for the $X_{0}$ and $X_{0.5}$ alloys, which increased with the increase in temperature from 700 to $1000^{\circ} \mathrm{C}$. Figure 14 shows the age hardening corresponding to the formation of the $\sigma$ phase in $\mathrm{X}_{0}$ and $\mathrm{X}_{0.5}$ alloys and the BCC phase in the $X_{1}$ alloy. Furthermore, the increase in the amount of the FCC phase led to age softening for the $\mathrm{X}_{0}, \mathrm{X}_{0.5}$, and $\mathrm{X}_{1}$ alloys. Analysis of the aging behavior of these three alloys revealed that the replacement of $\mathrm{Co}$ with $\mathrm{Ni}$ inhibits the formation of the $\sigma$ phase and a weak hardening effect, i.e., the effect of peak age hardening decreases from 25 to $16 \%$ from $x=0$ to $x=1$. In previous reports $[7,13,24]$, the hardness of $\sigma, B C C$, and FCC phases in HEAs were HV660, HV484, and HV208, respectively.

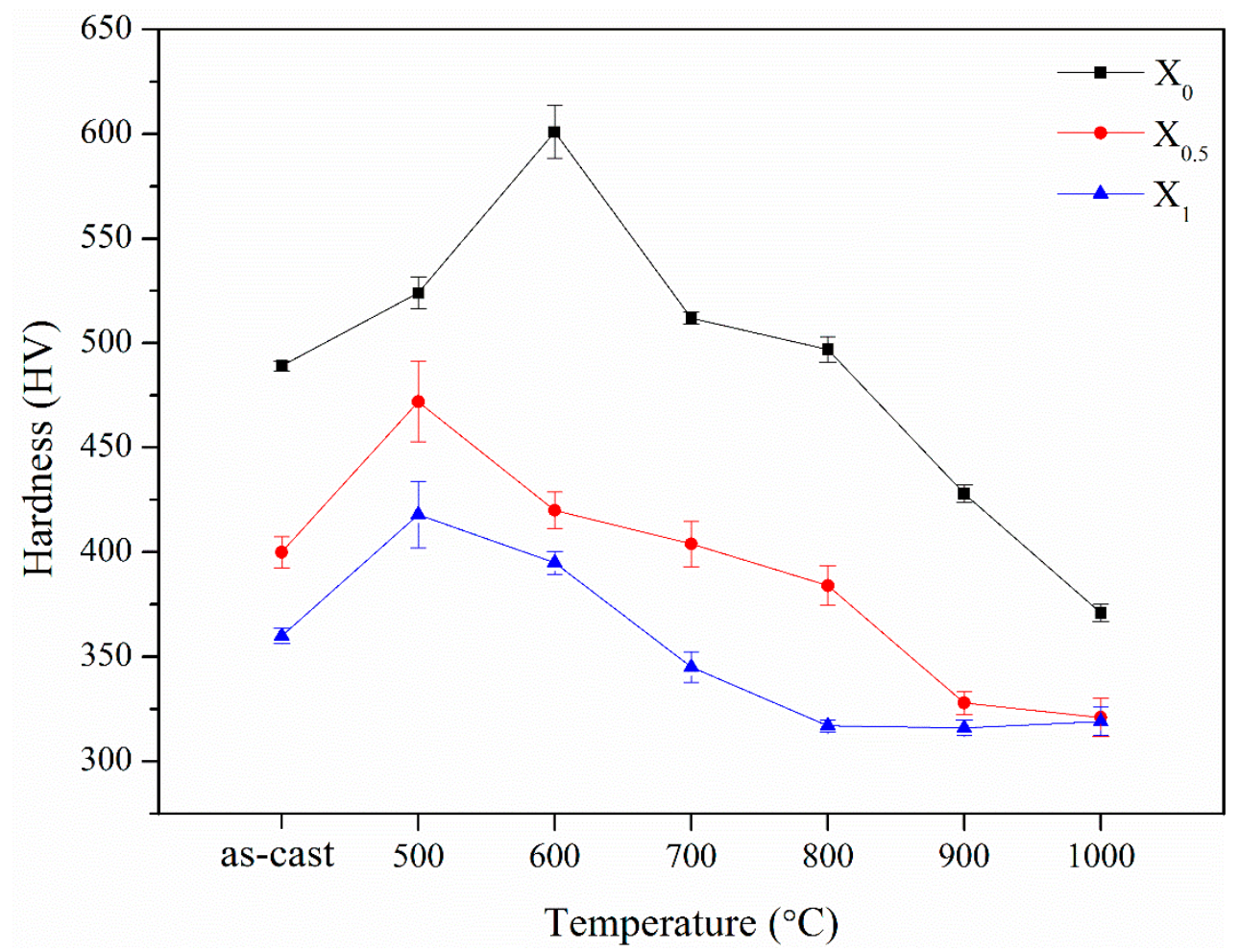

Figure 14. Variations in the hardness of the $X_{0}, X_{0.5}$, and $X_{1}$ as-cast alloys after aging for $144 \mathrm{~h}$ at $500-1000{ }^{\circ} \mathrm{C}$.

\subsubsection{Microstructure}

Figure 16 shows SEM-BSE images of the three aged alloys, and Table 9 lists chemical compositions of the interior structures marked in Figure 16. The results in Table 9 reveal that the $\sigma$ phase in the aged alloys was a $(\mathrm{Cr}, \mathrm{Fe})$-rich phase. The chemical composition characteristics of the B2, BCC, and FCC phases in the aged alloys were the same as those of the as-cast alloy, i.e., the $(\mathrm{Ni}, \mathrm{Al})$-rich phase, $(\mathrm{Cr}, \mathrm{Fe})$-rich phase, and $(\mathrm{Fe}, \mathrm{Cr}, \mathrm{Co})$-rich $/(\mathrm{Fe}, \mathrm{Cr}, \mathrm{Ni})$ rich or $(\mathrm{Ni}, \mathrm{Fe}, \mathrm{Cr})$-rich phase. The precipitation of the blocky $\sigma$ phase from the matrix at $600{ }^{\circ} \mathrm{C}$ for the $\mathrm{X}_{0}$ alloy caused peak age hardening (Figure 16a). The $\sigma$ phase completely dissolved into the B2 matrix, and the BCC and FCC phases underwent coarsening at $1000{ }^{\circ} \mathrm{C}$, leading to bottom age softening (Figure 16b). The precipitation of the blocky $\sigma$ phase from the matrix at $500{ }^{\circ} \mathrm{C}$ for the $\mathrm{X}_{0.5}$ alloy caused peak age hardening (Figure 16c). In Figure 16d, it can be seen that the disappearance of the $\sigma$ phase and coarsening of BCC and FCC phases led to bottom age softening at $1000{ }^{\circ} \mathrm{C}$. Comparison of Figure $8 \mathrm{~b}$ with Figure 16e reveals that Figure 16e shows the precipitation of fine and dense BCC particles from the $\mathrm{B} 2$ matrix, which led to peak age hardening at $500{ }^{\circ} \mathrm{C}$. The coarsening of the $\mathrm{BCC}$ and FCC phases led to bottom age softening at $1000^{\circ} \mathrm{C}$ (Figure 16f). 

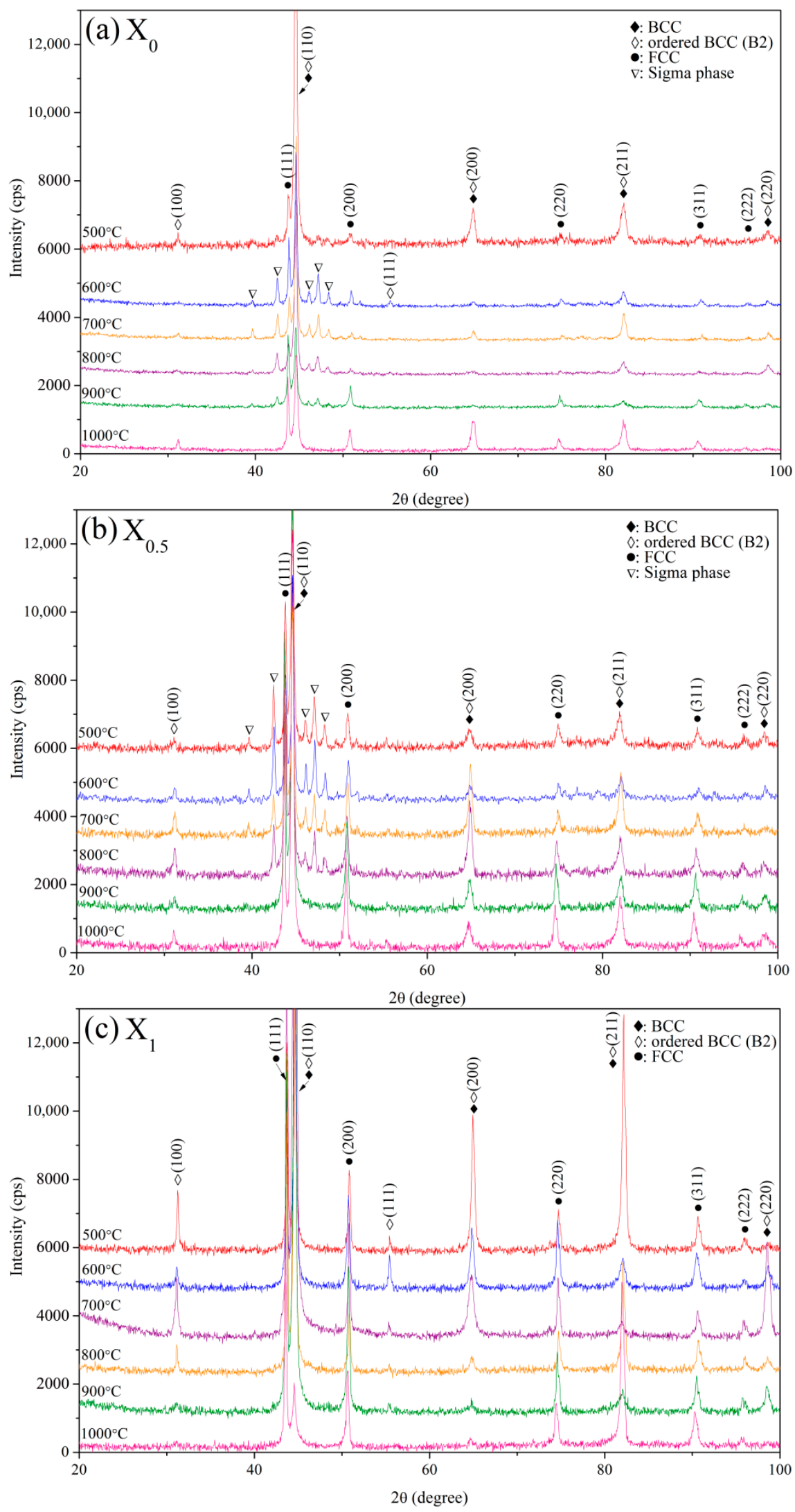

Figure 15. $X R D$ patterns of the three as-cast alloys after aging at $500-1000{ }^{\circ} \mathrm{C}$ for $144 \mathrm{~h}$ : (a) $\mathrm{X}_{0} ;$ (b) $\mathrm{X}_{0.5}$; and $(c) X_{1}$. 

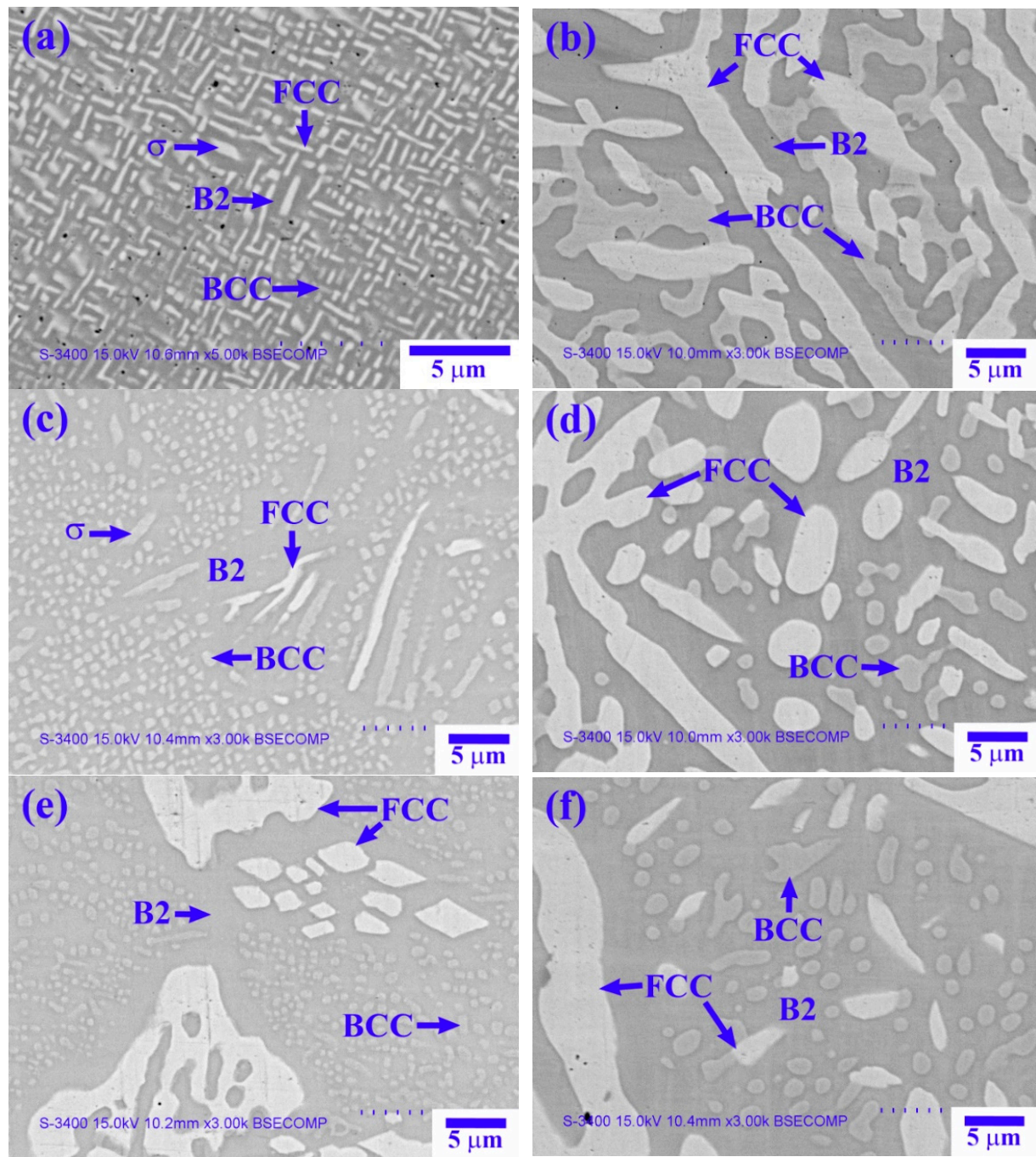

Figure 16. SEM-BSE images of the three aged alloys: $(\mathbf{a}, \mathbf{b}) \mathrm{X}_{0}$ at 600 and $1000{ }^{\circ} \mathrm{C} ;(\mathbf{c}, \mathbf{d}) \mathrm{X}_{0.5}$ at 500 and $1000{ }^{\circ} \mathrm{C}$; and $(\mathbf{e}, \mathbf{f}) \mathrm{X}_{1}$ at 500 and $1000^{\circ} \mathrm{C}$.

Table 9. Chemical composition (wt.\%) of the interior structures marked in Figure 16.

\begin{tabular}{|c|c|c|c|c|c|c|}
\hline Alloy & Phase & Al & Co & $\mathrm{Cr}$ & $\mathrm{Fe}$ & $\mathrm{Ni}$ \\
\hline \multirow[t]{4}{*}{$\mathrm{X}_{0}-600^{\circ} \mathrm{C}$} & B2 & $26.8 \pm 1.3$ & $20.8 \pm 1.4$ & $12.7 \pm 1.3$ & $15.6 \pm 1.9$ & $24.2 \pm 1.3$ \\
\hline & $\mathrm{BCC}$ & $14.7 \pm 1.5$ & $22.1 \pm 1.2$ & $27.7 \pm 1.7$ & $21.9 \pm 1.2$ & $13.6 \pm 1.5$ \\
\hline & $\sigma$ & $7.6 \pm 1.9$ & $21.4 \pm 1.8$ & $37.8 \pm 2.9$ & $25.3 \pm 1.7$ & $7.7 \pm 1.7$ \\
\hline & FCC & $8.6 \pm 0.7$ & $25.8 \pm 1.7$ & $23.0 \pm 1.1$ & $28.3 \pm 1.4$ & $14.3 \pm 1.1$ \\
\hline \multirow[t]{3}{*}{$\mathrm{X}_{0}-1000{ }^{\circ} \mathrm{C}$} & B2 & $32.1 \pm 2.4$ & $19.6 \pm 1.2$ & $8.2 \pm 0.4$ & $11.7 \pm 1.1$ & $28.5 \pm 1.8$ \\
\hline & $\mathrm{BCC}$ & $6.8 \pm 0.6$ & $20.3 \pm 1.1$ & $38.5 \pm 2.4$ & $25.2 \pm 0.7$ & $9.2 \pm 1.1$ \\
\hline & FCC & $6.7 \pm 1.0$ & $24.9 \pm 1.0$ & $26.6 \pm 1.4$ & $27.4 \pm 1.2$ & $14.4 \pm 0.6$ \\
\hline \multirow[t]{4}{*}{$\mathrm{X}_{0.5}-500^{\circ} \mathrm{C}$} & B2 & $32.5 \pm 2.1$ & $8.0 \pm 1.0$ & $6.0 \pm 0.8$ & $12.2 \pm 1.0$ & $41.3 \pm 1.5$ \\
\hline & $\mathrm{BCC}$ & $8.8 \pm 1.1$ & $17.5 \pm 1.6$ & $33.6 \pm 1.2$ & $26.7 \pm 1.6$ & $13.4 \pm 1.4$ \\
\hline & $\sigma$ & $4.6 \pm 1.4$ & $11.7 \pm 1.3$ & $41.8 \pm 3.1$ & $29.5 \pm 1.5$ & $12.4 \pm 1.1$ \\
\hline & FCC & $7.9 \pm 1.3$ & $15.0 \pm 1.8$ & $24.4 \pm 1.9$ & $27.9 \pm 0.7$ & $24.8 \pm 1.6$ \\
\hline \multirow{3}{*}{$\mathrm{X}_{0.5}-1000^{\circ} \mathrm{C}$} & B2 & $32.1 \pm 1.8$ & $7.8 \pm 1.6$ & $6.2 \pm 1.1$ & $12.4 \pm 1.4$ & $41.5 \pm 2.8$ \\
\hline & $\mathrm{BCC}$ & $9.3 \pm 1.1$ & $16.2 \pm 1.9$ & $34.0 \pm 1.3$ & $26.9 \pm 1.1$ & $13.6 \pm 0.4$ \\
\hline & FCC & $7.1 \pm 1.2$ & $14.1 \pm 1.2$ & $25.3 \pm 1.7$ & $28.6 \pm 1.9$ & $24.9 \pm 1.9$ \\
\hline \multirow[t]{3}{*}{$\mathrm{X}_{1}-500^{\circ} \mathrm{C}$} & B2 & $29.5 \pm 1.6$ & $\mathrm{~N} / \mathrm{A}$ & $5.3 \pm 0.9$ & $10.8 \pm 1.0$ & $54.3 \pm 2.5$ \\
\hline & $\mathrm{BCC}$ & $8.8 \pm 0.7$ & $\mathrm{~N} / \mathrm{A}$ & $50.1 \pm 2.0$ & $19.6 \pm 1.3$ & $21.5 \pm 1.3$ \\
\hline & FCC & $6.0 \pm 0.9$ & $\mathrm{~N} / \mathrm{A}$ & $27.0 \pm 1.5$ & $31.2 \pm 2.1$ & $35.9 \pm 1.6$ \\
\hline \multirow[t]{3}{*}{$\mathrm{X}_{1}-1000{ }^{\circ} \mathrm{C}$} & B2 & $29.5 \pm 2.1$ & $\mathrm{~N} / \mathrm{A}$ & $6.6 \pm 0.5$ & $10.8 \pm 1.5$ & $53.2 \pm 1.5$ \\
\hline & $\mathrm{BCC}$ & $9.0 \pm 1.5$ & $\mathrm{~N} / \mathrm{A}$ & $53.2 \pm 2.2$ & $19.4 \pm 1.7$ & $18.4 \pm 1.2$ \\
\hline & FCC & $6.6 \pm 1.7$ & $\mathrm{~N} / \mathrm{A}$ & $26.4 \pm 1.4$ & $30.7 \pm 1.1$ & $36.3 \pm 2.6$ \\
\hline
\end{tabular}




\section{Conclusions}

Three as-cast HEAs of $\mathrm{AlCo}_{1-\mathrm{x}} \mathrm{CoFeNi}_{1+\mathrm{x}}$ ( $\mathrm{x}$ is the molar ratio, where $\mathrm{x}=0,0.5,1$, denoted as $\mathrm{X}_{0}, \mathrm{X}_{0.5}$, and $\mathrm{X}_{1}$, respectively) exhibited a dendritic structure. The dendrites of the $\mathrm{X}_{0}, \mathrm{X}_{0.5}$, and $\mathrm{X}_{1}$ alloys comprised the $\mathrm{B} 2+\mathrm{BCC}+\mathrm{FCC}$ phases, $\mathrm{B} 2+\mathrm{BCC}$ phases, and $\mathrm{B} 2+\mathrm{BCC}$ phases, respectively. The interdendrite of the $\mathrm{X}_{0}, \mathrm{X}_{0.5}$, and $\mathrm{X}_{1}$ alloys comprised the B2 + FCC phases, B2 + FCC phases, and B2 + BCC + ordered FCC phases, respectively. By the replacement of Co with $\mathrm{Ni}$, the hardness decreased from HV480 to HV360, while the FCC phase volume fraction increased from 7.7 to $31.9 \%$. From $X_{0}$ to $X_{1}$ alloys, the $\sigma_{y}$ and $\sigma_{\max }$ decreased from 1202 and $1790 \mathrm{MPa}$ to 693 and $1537 \mathrm{MPa}$, respectively. However, $\varepsilon_{\mathrm{f}}$ increased from 0.15 to 0.42 . For the $\mathrm{X}_{0}$ alloy, peak age hardening occurred at $600{ }^{\circ} \mathrm{C}$ because of the precipitation of the $\sigma$ phase. The peak age hardening for the $X_{0.5}$ and $\mathrm{X}_{1}$ alloys, which was caused by the precipitation of the $\sigma$ and BCC phases, respectively, was observed at $500{ }^{\circ} \mathrm{C}$. Age softening for the $\mathrm{X}_{0}, \mathrm{X}_{0.5}$, and $\mathrm{X}_{1}$ alloys was observed at 900-1000 ${ }^{\circ} \mathrm{C}, 800-1000{ }^{\circ} \mathrm{C}$, and $700-1000{ }^{\circ} \mathrm{C}$, respectively, because of the increase in the amount of the FCC phase and coarsening of the BCC phase. The replacement of Co with $\mathrm{Ni}$ effectively improved the strength-ductility balance.

Author Contributions: Conceptualization, T.-T.S. and C.-F.L.; validation, C.-F.L. and T.-T.S.; formal analysis, C.-F.L.; investigation, C.-F.L.; writing—original draft preparation, C.-F.L.; writing-review and editing, T.-T.S.; visualization, C.-F.L. and T.-T.S.; supervision, T.-T.S. All authors have read and agreed to the published version of the manuscript.

Funding: This research was funded by the "High Entropy Materials Center" from The Featured Areas Research Center Program within the framework of the Higher Education Sprout Project by the Ministry of Education (MOE) and from the Projects MOST 110-2634-F-007-024 by Ministry of Science and Technology (MOST) in Taiwan.

Institutional Review Board Statement: Not applicable.

Informed Consent Statement: Not applicable.

Data Availability Statement: Data sharing not applicable.

Conflicts of Interest: The authors declare no conflict of interest.

\section{References}

1. Yeh, J.W.; Chen, S.K.; Gan, J.Y.; Chin, T.S.; Shun, T.T.; Tsau, C.H.; Chang, S.Y. Nanostructured high-entropy alloys with multiple principal elements novel alloy design concepts and outcomes. Adv. Eng. Mater. 2004, 6, 299-303. [CrossRef]

2. Yeh, J.W. Alloy design strategies and future trends in high-entropy alloys. J. Met. 2013, 65, 1759-1771. [CrossRef]

3. Tong, C.J.; Chen, Y.L.; Chen, S.K.; Yeh, J.W.; Shun, T.T.; Tsau, C.H.; Lin, S.J.; Chang, S.Y. Microstructure characterization of $\mathrm{Al}_{\mathrm{x}} \mathrm{CoCrCuFeNi}$ high-entropy alloy system with multiprincipal elements. Metall Mater. Trans. A Phys. Metall Mater. Sci. 2005, 36A, 881-893. [CrossRef]

4. Tong, C.J.; Chen, M.R.; Chen, S.K.; Yeh, J.W.; Shun, T.T.; Lin, S.J.; Chang, S.Y. Mechanical Performance of the Al $\mathrm{Al}_{\mathrm{x}} \mathrm{CoCrCuFeNi}$ High-Entropy Alloy System with Multiprincipal Elements. Metall Mater. Trans. A Phys. Metall Mater. Sci. 2005, 36A, $1263-1271$. [CrossRef]

5. Chen, Y.Y.; Duval, T.; Hung, U.D.; Yeh, J.W.; Shih, H.C. Microstructure and electrochemical properties of high entropy alloys-a comparison with type-304 stainless steel. Corros. Sci. 2005, 47, 2257-2279. [CrossRef]

6. Wu, J.M.; Lin, S.J.; Yeh, J.W.; Chen, S.K.; Hung, Y.S.; Chen, H.C. Adhesive wear behavior of $\mathrm{Al}_{\mathrm{x}} \mathrm{CoCrCuFeNi} \mathrm{high-entropy} \mathrm{alloys}$ as a function of aluminum content. Wear 2006, 261, 513-519. [CrossRef]

7. Tung, C.C.; Yeh, J.W.; Shun, T.T.; Chen, S.K.; Hung, Y.S.; Chem, H.C. On the elemental effect of AlCoCrCuFeNi high-entropy alloy system. Mater. Lett. 2007, 61, 1-5. [CrossRef]

8. Wen, L.H.; Kou, H.C.; Li, J.S.; Chang, H.; Xue, X.Y.; Zhou, L. Effect of aging temperature on microstructure and properties of AlCoCrCuFeNi high-entropy alloy. Intermetallics 2009, 17, 266-269. [CrossRef]

9. Tsai, C.W.; Chen, Y.L.; Tsai, M.H.; Yeh, J.W.; Shun, T.T.; Chen, S.K. Deformation and annealing behaviors of high-entropy alloy $\mathrm{Al}_{0.5}$ CoCrCuFeNi. J. Alloys Compd. 2009, 486, 427-435. [CrossRef]

10. Zhang, K.B.; Fu, Z.Y.; Zhang, J.Y.; Shi, J.; Wang, W.M.; Wang, H.; Wang, Y.C.; Zhang, Q.J. Annealing on the structure and properties evolution of the CoCrFeNiCuAl high-entropy alloy. J. Alloys Compd. 2010, 502, 295-299. [CrossRef]

11. Tsai, C.W.; Tsai, M.H.; Yeh, J.W.; Yang, C.C. Effect of temperature on mechanical properties of $\mathrm{Al}_{0.5} \mathrm{CoCrCuFeNi}$ wrought alloy. J. Alloys Compd. 2010, 490, 160-165. [CrossRef] 
12. Singh, S.; Wanderka, N.; Murty, B.S.; Glatzel, U.; Banhart, J. Decomposition in multi-component AlCoCrCuFeNi high-entropy alloy. Acta Mater. 2011, 59, 182-190. [CrossRef]

13. Kaoa, Y.F.; Chen, T.J.; Chen, S.K.; Yeh, J.W. Microstructure and mechanical property of as-cast, -homogenized, and-deformed $\mathrm{Al}_{\mathrm{x}} \mathrm{CoCrFeNi}(0 \leq \mathrm{x} \leq 2)$ high-entropy alloys. J. Alloys Compd. 2009, 488, 57-64. [CrossRef]

14. Munitz, A.; Salhov, S.; Hayun, S.; Frage, N. Heat treatment impacts the micro-structure and mechanical properties of AlCoCrFeNi high entropy alloy. J. Alloys Compd. 2016, 683, 221-230. [CrossRef]

15. Wang, Y.P.; Li, B.S.; Ren, M.X.; Yang, C.; Fu, H.Z. Microstructure and compressive properties of AlCrFeCoNi high entropy alloy. Mater. Sci. Eng. A 2008, 491, 154-158. [CrossRef]

16. Lee, S.K.; Kang, J.H.; Lim, K.R.; Na, Y.S. Influence of compressive strain on the microstructural evolution of an AlCoCrFeNi high entropy alloy. Mater. Charact. 2017, 132, 162-168. [CrossRef]

17. Haghdadi, N.; Guo, T.; Ghaderi, A.; Hodgson, P.D.; Barnett, M.R.; Fabijanic, D.M. The scratch behaviour of $\mathrm{Al}_{X} \mathrm{CoCrFeNi}(\mathrm{x}=0.3$ and 1.0) high entropy alloys. Wear 2019, 428-429, 293-301. [CrossRef]

18. Lu, J.; Zhang, H.; Chen, Y.; Luo, L.; Guo, F.; Xiao, P. Oxidation behavior of gas-atomized AlCoCrFeNi high-entropy alloy powder at $900-1100{ }^{\circ}$ C. Corros. Sci. 2021, 181, 2257-2279. [CrossRef]

19. Kang, M.; Lim, K.R.; Won, J.W.; Na, Y.S. Effect of Co content on the mechanical properties of A2 and B2 phases in AlCo $\mathrm{CrFeNi}$ high-entropy alloys. J. Alloys Compd. 2018, 769, 808-812. [CrossRef]

20. Ke, G.Y.; Chen, S.K.; Hsu, T.; Yeh, J.W. FCC and BCC equivalents in as-cast solid solution of $\mathrm{Al}_{\mathrm{x}} \mathrm{Co}_{\mathrm{y}} \mathrm{Cr}_{\mathrm{z}} \mathrm{Cu}_{0.5} \mathrm{Fe}_{\mathrm{v}} \mathrm{Ni}_{\mathrm{w}}$ high-entropy alloys. Ann. Chim. Sci. Mater. 2006, 31, 669-684. [CrossRef]

21. Sugimoto, K.; Usui, N.; Kobayashi, M.; Hashimoto, S. Effects of volume fraction and stability of retained austenite on ductility of TRIP-aided dual-phase steels. ISIJ Int. 1992, 32, 1311-1318. [CrossRef]

22. Porter, D.A.; Easterling, K.E.; Sherif, M.Y. Phase Transformations in Metals and Alloys, 3rd ed.; CRC Press: New York, NY, USA, 2009; pp. 23-24. ISBN 978-1-4200-6210-6.

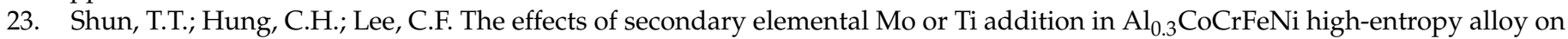
age hardening at $700{ }^{\circ} \mathrm{C}$. J. Alloys Compd. 2010, 495, 55-58. [CrossRef]

24. Shun, T.T.; Chang, L.Y.; Shiu, M.H. Microstructure and mechanical properties of multiprincipal component CoCrFeNiMox alloys. Mater. Charact. 2012, 70, 63-67. [CrossRef] 